\title{
Pelatihan Penerapan Pendekatan Kontekstual dalam Pembelajaran Tematik bagi Guru MIN Korong Gadang Kota Padang
}

\author{
Abdul Basit ${ }^{1}$, Debi Febrianto², Usdarisman ${ }^{3}$, \\ ${ }^{1}$ Universitas Islam Negeri Imam Bonjol Padang, abdulbasit@uinib.ac.id \\ ${ }^{2}$ Universitas Islam Negeri Imam Bonjol Padang, debifebianto@uinib.ac.id \\ ${ }^{3}$ Universitas Islam Negeri Imam Bonjol Padang, undarisma@uinib.ac.id
}

2021 by the authors. Submitted for possible open access publication under the terms and conditions of the Creative Commons Attribution-ShareAlike 4.0 International License-(CC-BY-SA) (https://creativecommons.org/licenses/by-sa/4.0/)

do) DOI: http://dx.doi.org/10.30983/dedikasia.vli2.5030

\begin{tabular}{ll} 
ARTICLE INFO \\
\hline Submit & $: 07$ Agustus 2021 \\
Revised & $: 06$ Desember 2021 \\
Accepted & $: 30$ Desember 2021
\end{tabular}

Keywords:

Training; approach, contextual, thematic, integrative
International License-(CC-BY-SA)

(https://creativecommons.org/licenses/by-sa/4.0/)

do) $h t t p: / / d x . d o i . o r g / 10.30983 /$ dedikasia.vli2.5030

\begin{abstract}
The goal is to have meaningful learning for MIN Korong Gadang students through the application of a contextual approach in thematic learning and learning plan documents that have thematic contextual nuances by incorporating three national education agendas, namely strengthening character education, strengthening literacy, and 2lst century learning. quality learning outcomes in schools. The method of this community service activity uses the lecture, demonstration, and discussion methods. The results of this training can be declared successful. This can be seen from: (l) The attendance of participants is in accordance with the target of 95\% (23 out of 25 teachers) (2) the results of the training are stated to be very good according to the analysis of the performance appraisal rubric. (3) Participants are very enthusiastic about participating in the training, which can be seen from the seriousness of participating in the training, the many questions that arise in the mentoring process and the willingness of the teacher to apply a contextual approach in thematic learning as well as create curriculum documents in the form of contextual and thematic syllabus and lesson plans that are integrative.

Keywords: approach, contextual, thematic, integrative
\end{abstract}

\section{Introduction}

Disadari bahwa guru merupakan kunci utama keberhasilan proses pembelajaran di sekolah. Oleh karena itu, harapan keberhasilan pendidikan sering dibebankan pada guru. Salah satu hal mendasar yang penting disikapi oleh guru adalah kesiapan mental terhadap perubahan yang terjadi saat ini. Guru tidak boleh terjebak dalam rutinitas dan formalitas. Masih banyak guru yang enggan mengupdate informasi atau meningkatkan pengetahuan dan keterampilan terkait profesi. Di lapangan masih banyak guru yang belum selesai dengan urusannya sendiri. Masih sibuk untuk halhal yang di luar konteks menciptakan pembelajaran yang efektif.

Pembangunan Nasional di bidang pengembangan sumber daya manusia Indonesia yang berkualitas melalui pendidikan merupakan upaya yang sungguh-sungguh dan terus-menerus dilakukan untuk mewujudkan manusia Indonesia seutuhnya. Sumber daya yang berkualitas akan menentukan mutu kehidupan pribadi, masyarakat, dan bangsa dalam rangka mengantisipasi, mengatasi persoalan-persoalan, dan tantangan-tantangan yang terjadi dalam masyarakat pada masa kini dan masa depan. 
Salah satu permasalahan yang dihadapi oleh bangsa Indonesia adalah rendahnya mutu pendidikan, khususnya pendidikan dasar dan menengah. Berbagai usaha telah dilakukan untuk meningkatkan mutu pendidikan nasional, antara lain melalui berbagai pelatihan dan peningkatan kualitas guru, penyempurnaan kurikulum, pengadaan buku dan alat pelajaran, perbaikan sarana dan prasarana pendidikan lain, dan peningkatan mutu manajemen sekolah, namun demikian, berbagai indikator mutu pendidikan belum menunjukkan peningkatan yang memadai.

Upaya peningkatan kualitas pendidikan di Indonesia tidak pernah berhenti. Berbagai terobosan baru terus dilakukan oleh pemerintah melalui Depdiknas. Upaya itu antara lain dalam pengelolaan sekolah, peningkatan sumber daya tenaga pendidikan, pengembangan/penulisan materi ajar, serta pengembangan paradigma baru dalam metodologi pengajaran.

Mengajar bukan semata persoalan menceritakan. Belajar bukanlah konsekuensi otomatis dari perenungan informasi ke dalam benak siswa. Belajar memerlukan keterlibatan mental dan kerja siswa sendiri. Penjelasan dan pemeragaan semata tidak akan meningkatkan hasil belajar. Salah satu upaya untuk meningkatkan hasil belajar siswa secara optimal adalah pendekatan kontekstual.

Guru sebagai pengelola pembelajaran dituntut harus mampu menciptakan situasi dan kondisi yang memungkinkan siswa belajar secara berdaya guna dan berhasil guna. Suatu upaya agar tercipta kondisi yang kondusif sehingga siswa dapat belajar secara optimal, yaitu dengan melaksanakan pembelajaran yang menggunakan pendekatan yang dapat membuat siswa belajar secara mudah dan dengan perasaan senang. Salah satu prinsip yang dikembangkan dalam pembelajaran di kelas adalah berpusat pada potensi, perkembangan, kebutuhan, dan kepentingan peserta didik dan lingkungannya. Apa artinya? Artinya proses pembelajaran dikembangkan berdasarkan prinsip bahwa peserta didik memiliki posisi sentral untuk mengembangkan kompetensinya. Peserta didik memiliki posisi sentral mempunyai makna bahwa kegiatan pembelajaran berpusat pada peserta didik. Pendekatan pembelajaran di sekolah yang diduga akan sejalan dengan harapan dari kurikulum dan dapat meningkatkan berpikir kritis siswa adalah pendekatan kontekstual. Dalam pembelajaran yang menggunakan pendekatan kontekstual materi disajikan melalui konteks yang bervariasi dan berhubungan dengan kehidupan siswa baik di rumah, di sekolah maupun di masyarakat secara luas, dan pengetahuan didapat oleh siswa secara konstruktivis.

Seiring perkembangan ilmu pengetahuan dan teknologi paradigma pembelajaran di sekolah ini pun telah banyak mengalami perubahan antara lain perubahan proses pembelajaran, salah satunya adalah pembelajaran kontekstual. Sebagai suatu konsep pembelajaran yang mengkaitkan materi pembelajaran dengan dunia nyata serta mendorong siswa membangun antara pengetahuan yang dimilikinya dengan penerapan kehidupan mereka sehari-hari.

Berdasarkan paradigma tersebut, pembelajaran pada jenjang SD/ MI ditujukan untuk menumbuh kembangkan keterampilan siswa dalam mempersiapkan, membina, dan mengoptimalkan kemampuan peserta didik, menguasai kemampuan dasar yang diperlukan bagi kehidupannya di masyarakat. Pendekatan Kontekstual/Contextual Teaching Learning (CTL) dapat dijadikan salah satu alternatif agar siswa dapat belajar dengan kreatif dan lebih mudah memahami konsep-konsep pembelajaran yang bermakna. sehingga dapat meningkatkan kemampuan pemecahan masalah, baik ketika mereka sekolah maupun ketika sudah di lingkungan masyarakat.

Pendekatan Kontekstual/Contextual Teaching Learning (CTL), memiliki kelebihan diantaranya, siswa dapat lebih termotivasi karena materi yang disajikan terkait dengan kehidupan sehari-hari. Juga merupakan sistem belajar yang didasarkan pada filosofi bahwa siswa mampu menyerap pelajaran apabila mereka menangkap makna dalam materi akademis yang mereka terima, 
dan mereka menangkap makna dalam tugas-tugas sekolah jika mereka bisa mengkaitkan informasi baru dengan pengetahuan dan pengalaman yang sudah mereka miliki sebelumnya. (Johnson, 2002)

Pada intinya Pendekatan Kontekstual/Contextual Teaching Learning (CTL) merupakan upaya inovasi pendidikan yang menekankan pada meaningful learning atau pembelajaran yang bermakna dengan cara mengkaitkan materi pembelajaran dengan kehidupan nyata (contextual). Sehingga diharapkan dapat meningkatkan hasil belajar siswa, karena pembelajaran menjadi lebih bermakna.

Desentralisasi pengelolaan pendidikan yang diharapkan dapat memenuhi kebutuhan dan kondisi daerah perlu segera dilaksanakan. Bentuk nyata dari desentralisasi pengelolaan pendidikan ini adalah diberikannya kewenangan kepada madrasah untuk mengambil keputusan berkenaan dengan pengelolaan pendidikan, seperti dalam pengelolaan kurikulum, baik dalam penyusunannya maupun pelaksanaannya di madrasah. Tujuan pendidikan tingkat satuan pendidikan dirumuskan mengacu pada tujuan umum pendidikan. Adapun tujuan umum pendidikan adalah meletakkan dasar kecerdasan, pengetahuan, kepribadian, akhlak mulia serta keterampilan untuk hidup mandiri dan mengikuti pendidikan lebih lanjut.

Mengacu pada tujuan umum tersebut, dapat dijabarkan tujuan pendidikan sebagai berikut:

1. Meningkatkan keimanan dan ketakwaan serta akhlak mulia.

2. Meningkatkan potensi, kecerdasan, dan minat sesuai dengan tingkat perkembangan dan kemampuan peserta didik.

3. Membekali peserta didik dengan pengetahuan yang memadai agar dapat melanjutkan ke jenjang pendidikan yang lebih tinggi.

4. Mengembangkan keragaman potensi dan karakteristik daerah dan lingkungan untuk menghasilkan lulusan yang dapat memberikan konstribusi bagi pengembangan daerah.

5. Mendukung pelaksanaan pembangunan daerah dan nasional.

6. Mengembangkan ilmu pengetahuan, teknologi dan seni.

7. Mendukung peningkatan rasa toleransi dan kerukunan antar umat beragama.

8. Mendorong peserta didik agar mampu bersaing secara global sehingga dapat hidup berdampingan dengan anggota masyarakat bangsa lain.

9. Mendorong wawasan dan sikap kebangsaan dan persatuan nasional untuk memperkuat keutuhan bangsa dalam Negara Kesatuan Republik Indonesia.

10. Menunjang kelestarian dan keragaman budaya.

11. Mendorong tumbuh kembangnya kesetaraan jender.

12. Mengembangkan visi, misi, tujuan madrasah/sekolah, kondisi dan ciri khas madrasah/sekolah.

Berdasarkan beberapa observasi awal menunjukkan bahwa pengembangan kurikulum di MIN Korong Gadang memiliki banyak masalah, baik yang berkenaan dengan aspek kinerja guru rumpun mata pelajaran dalam mengelola pembelajaran, isi dokumen kurikulum, maupun proses pembelajaran di kelas. Kurikulum di MIN lebih menawarkan minimum informasi (menjawab pertanyaan bagaimana), dengan sebaran materi yang tumpang tindih, saling terpisah antar rumpun. 
Sebagian besar guru sering terpaku pada materi yang disajikan buku penerbit, sehingga semangat memperkaya isi kurikulum dan pengalaman belajar kurang tumbuh. Guru MIN juga masih kaku atau terkesan gagap dalam menerapkan pembelajaran tematik di kelas.

Pembelajaran di MIN Korong Gadang cenderung menggunakan pendekatan yang normatif, yaitu menyajikan norma-norma Islam tanpa ilustrasi konteks sosial budaya (kontekstual), sehingga siswa kurang menghayati nilai agama. Pada sisi lain, guru juga kurang berupaya dalam menggali berbagai metode dan strategi yang mungkin bisa dipakai lebih sesuai dengan karakteristik tujuan untuk pembelajaran di kelas rendah dan tinggi pada sekolah Madrasah Ibtidaiyah.

Berdasarkan beberapa faktor yang bermasalah tersebut, pendekatan kontekstual sebagai hal yang paling mendasar, kami sebagai TIM Pengabdi UIN Imam Bonjol Padang ingin memberikan pendampingan. Sehingga perlu dikaji lebih mendalam, membuat rencana pembelajaran yang bermakna dan memberikan pengalaman belajar yang dekat dengan keseharian mereka serta melaksanakannya secara baik dan mencarikan alternatif solusi dalam bentuk kegiatan pengabdian.

Permasalahan yang dihadapi oleh mitra yakni MIN Korong Gadang selama ini adalah sebagai berikut :

1. Sebagian guru belum pernah mendapatkan pelatihan tentang penerapan pendekatan kontekstual dalam pembelajaran tematik di madrasah ibtidaiyah

2. Minimnya pemahaman sebagian guru tentang Penerapan pendekatan kontekstual dan pembelajaran tematik;

3. Kebutuhan guru akan adanya sebuah pelatihan tentang pembelajaran tematik terpadu, penyusunan kurikulum yang bernuansa kontekstual dan mekanisme pelaksanaannya dalam pembelajaran di kelas.

\section{Methods}

Metode yang digunakan dalam pengabdian masyarakat ini adalah metode service learning (SL) yang merupakan salah satu metode pengabdian masyarakat di bidang pendidikan. Pelaksanaan dalam kegiatan ini adalah mencakup penyajian materi, workshop, pendampingan dan evaluasi yang dilaksanakan secara berkelanjutan.

\section{Metode Kegiatan}

a. Memberikan materi tentang pendekatan kontekstual (Contextual Teaching and Learning) dan ruang lingkupnya.

Memberikan materi tentang penerapan pendekatan kontekstual dalam penyusunan dokumen kurikulum dan pelaksanaannya di sekolah;

b. Memberikan pelatihan tentang pembelajaran tematik, bagaimana langkah penyusunan program tahunan, program semeter, Silabus dan RPP yang menggunakan pendekatan kontekstual.

c. Memberikan pendampingan pada praktik tentang pembuatan dokumen kurikulum tematik yang sesuai dengan satuan tingkat pembelajaran dan menggunakannya dalam pembelajaran di kelas; 
d. Melakukan pendampingan secara berkala sampai kepada peserta dapat secara mandiri menerapkan pendekatan kontekstual pada proses belajar mengajar tematik di kelas.

\section{Rencana Kegiatan}

Rencana kegiatan ini dilakukan secara langsung kepada sasaran selama kegiatan pelatihan.

a. Pra pelatihan. Meninjau pengetahuan guru-guru dan operator sekolah tentang pentingnya pendekatan kontekstual pada pembelajaran tematik;

b. Pelatihan dan pendampingan. Memantau guru-guru dan operator sekolah terhadap penerapan pendekatan kontekstual pada penyusunan dan pelaksanaan kurikulum tematik;

c. Pasca pelatihan. Melihat perkembangan penerapan pendekatan kontekstual pada penyusunan dokumen kurikulum dan Proses belajar mengajar tematik di kelas secara mandiri atau dengan bantuan tim pakar

\section{Results}

Madrasah Ibtidaiyah Negeri (MIN) Korong Gadang adalah Madrasah Ibtidaiyah Negeri yang terletak di Provinsi Sumatera Barat, Padang. Sekolah ini menggunakan Agama Islam sebagai pegangan utama pendidikan Agamanya. Nomor statistik Npsn 10303537. MIN Korong Gadang memiliki 25 Guru, dua pegawai Tata Usaha (TU), tiga tenaga administrasi, dua pegawai pustaka dan satu penjaga sekolah.

\begin{tabular}{|l|l|l|}
\hline \multicolumn{2}{|l|}{ Data Sarpras } \\
\hline No & Uraian & Jumlah \\
\hline 1 & Ruang Kelas & 7 \\
\hline 2 & Ruang Lab & 2 \\
\hline 3 & Ruang Kantor dan Perpus & 1 \\
\hline \multicolumn{2}{|l|}{ TOTAL } & 10 \\
\hline
\end{tabular}

Adapun rombel ada 7 dengan sebaran siswa sebagai berikut;

\begin{tabular}{|l|l|l|l|l|}
\hline \multicolumn{5}{|l|}{ Data Rombongan Belajar } \\
\hline No & Uraian & Detail & Jumlah & Total \\
\hline \multirow{2}{*}{1} & \multirow{2}{*}{ Kelas 1 } & A & 31 & \multirow{2}{*}{62} \\
\cline { 3 - 4 } & & B & 31 & \\
\hline \multirow{2}{*}{2} & \multirow{2}{*}{ Kelas 2 } & A & 23 & \multirow{2}{*}{55} \\
\cline { 3 - 4 } & & B & 22 & 50 \\
\hline 3 & Kelas 3 & A & 25 & \multicolumn{2}{|l}{} \\
\cline { 3 - 4 } & & &
\end{tabular}




\begin{tabular}{|l|l|l|l|l|} 
& & B & 25 & \\
\hline \multirow{2}{*}{4} & \multirow{2}{*}{ Kelas 4 } & A & 31 & \multirow{2}{*}{63} \\
\cline { 3 - 4 } & & B & 32 & \\
\hline \multirow{2}{*}{5} & \multirow{2}{*}{ Kelas 5 } & A & 26 & \multirow{2}{*}{53} \\
\cline { 3 - 4 } & \multirow{2}{*}{6} & B & 27 & \\
\hline \multicolumn{2}{|l|}{ Kumlah 6 } & A & 25 & \multirow{2}{*}{50} \\
\cline { 3 - 4 } & & B & 25 & \\
\hline
\end{tabular}

Lokasi sekolah berada di wilayah Tampat Durian, Korong Gadang kota Padang. Tempatnya tenang dan nyaman, memungkinkan siswa bisa belajar dengan serius tanpa ada gangguan karena berada di areal yang jauh dari jalan raya kota Padang.

Banyaknya kelas dan rombel di MIN Korong Gadang, membuat guru mengalami kelemahan dari sisi proses pembelajaran dan sarana prasarana. Fasilitas penunjang seperti perpustakaan dan laboratorium belum ada, Para guru masih kurang atau lemah dalam memahami konsep dasar dan penyusunan dokumen kurikulum. Guru masih cenderung menggunakan buku pedoman yang dibeli dari penerbit sebagai media sekaligus sumber belajar. Sebagian besar guru belum pernah mendapatkan pelatihan dan bimbingan tentang penerapan pendekatan kontekstual serta lemah dalam penyusunan dokumen kurikulum. Lemahnya kemampuan guru dalam menerapkan pendekatan kontekstual dalam penyusunan kurikulum. Kurangnya pengetahuan tentang pembelajaran tematik dan pelaksanaannya di kelas.

Permasalahan ini membutuhkan bantuan pengabdian dalam rangka menemukan solusi kongkrit menjawab permasalahan di sekolah. Kebutuhan guru akan adanya sebuah pelatihan dan pendampingan tentang penerapan pendekatan kontekstual dalam pembelajaran tematik secara intensif sangat diperlukan.

Pelaksanaan Kegiatan pelatihan ini membutuhkan beberapa persiapan diantaranya sebagai berikut:

a. Melakukan studi pustaka tentang konsep pendekatan kontekstual dan pembelajaran tematik di MI yang masih sulit disusun oleh guru serta cara pelaksanaannya.

b. Melakukan persiapan untuk pembuatan dokumen kurikulum yang menggunakan pendekatan kontekstual tematik terdiri dari prota, promes, silabus dan RPP.

c. Melakukan praktik penerapan pendekatan kontekstual pada pembelajaran tematik pada jenjang kelas rendah dan kelas tinggi.

d. Menentukan waktu pelaksanaan dan lamanya kegiatan pengabdian bersama-sama tim pelaksana 
e. Menentukan dan mempersiapkan materi yang akan disampaikan dalam kegiatan pengabdian masyarakat.

Pelaksanaan kegiatan pengabdian berlangsung pada hari Kamis-Jumat, 7-8 September 2021 dari jam 07.30 WIB s.d 17.00 WIB, dengan dihadiri 30 orang peserta, guru-guru MIN Korong Gadang. Kegitan berupa penyampaian materi dan praktik langsung penerapan pendekatan kontekstual dalam pembelajaran tematik. Peserta dibagi dalam 7 kelompok terdiri dari 3/4 orang anggota. Setiap kelompok melakukan diskusi bedah kurikulum dan bahan ajar setelah diberikan penjelasan oleh tim instruktur.

Pelaksanaan kegiatan pengabdian yang dilakukan menghasilkan beberapa kegiatan berikut ini:

a. Sosialisasi kegiatan pengabdian antara ketua TIM Pengabdian UIN Imam Bonjol Padang dengan Kepala Madrasah Ibtidaiyah Negeri Korong Gadang.

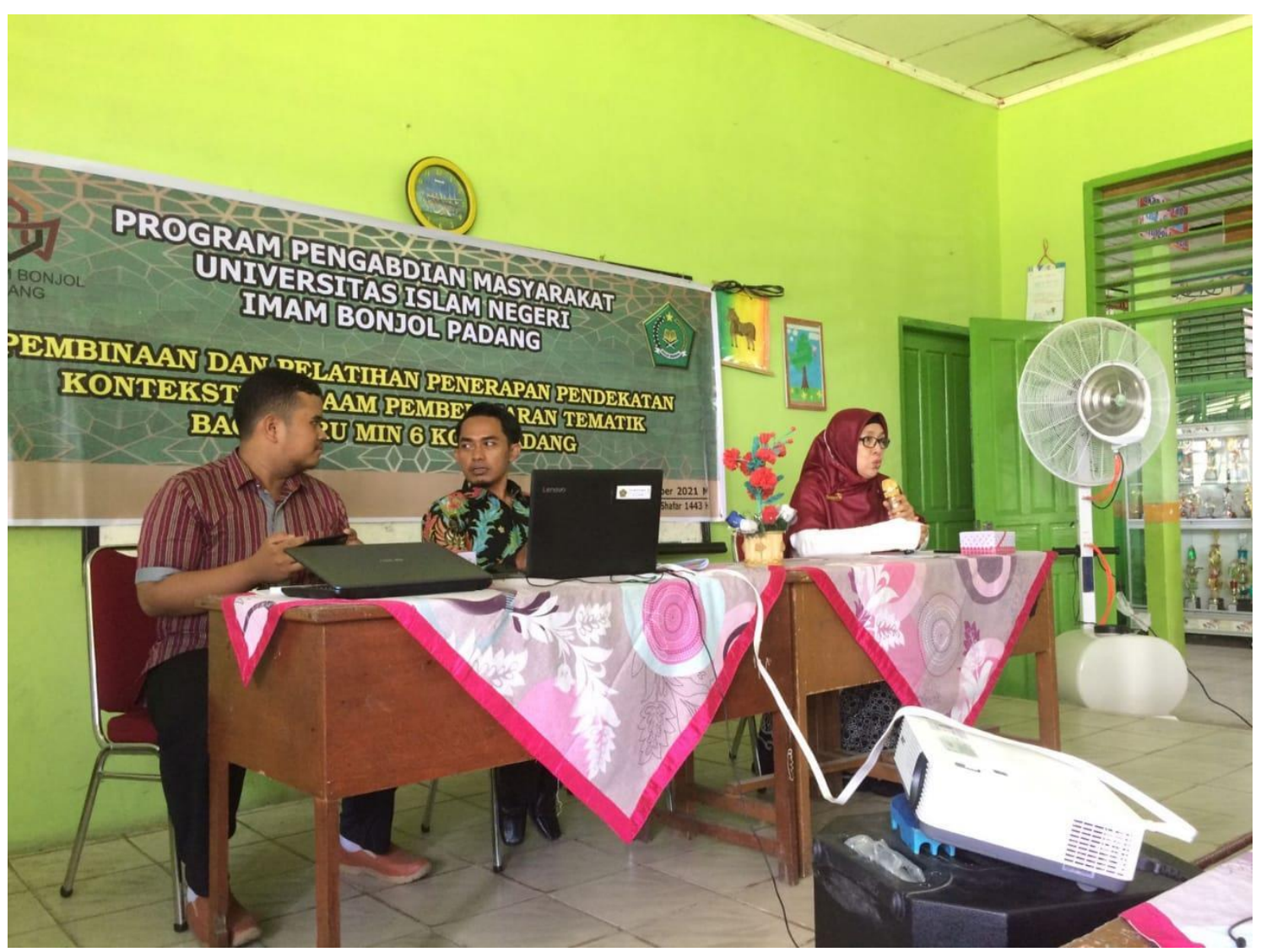

Gambar l. Kegiatan sosialisasi program (sumber : dokumen, 2021)

b. Terjalinnya kerjasama antara Tim Pengabdian UIN Imam Bonjol Padang dengan Kepala Madrasah Ibtidaiyah Negeri Korong Gadang dalam bidang pendidikan 


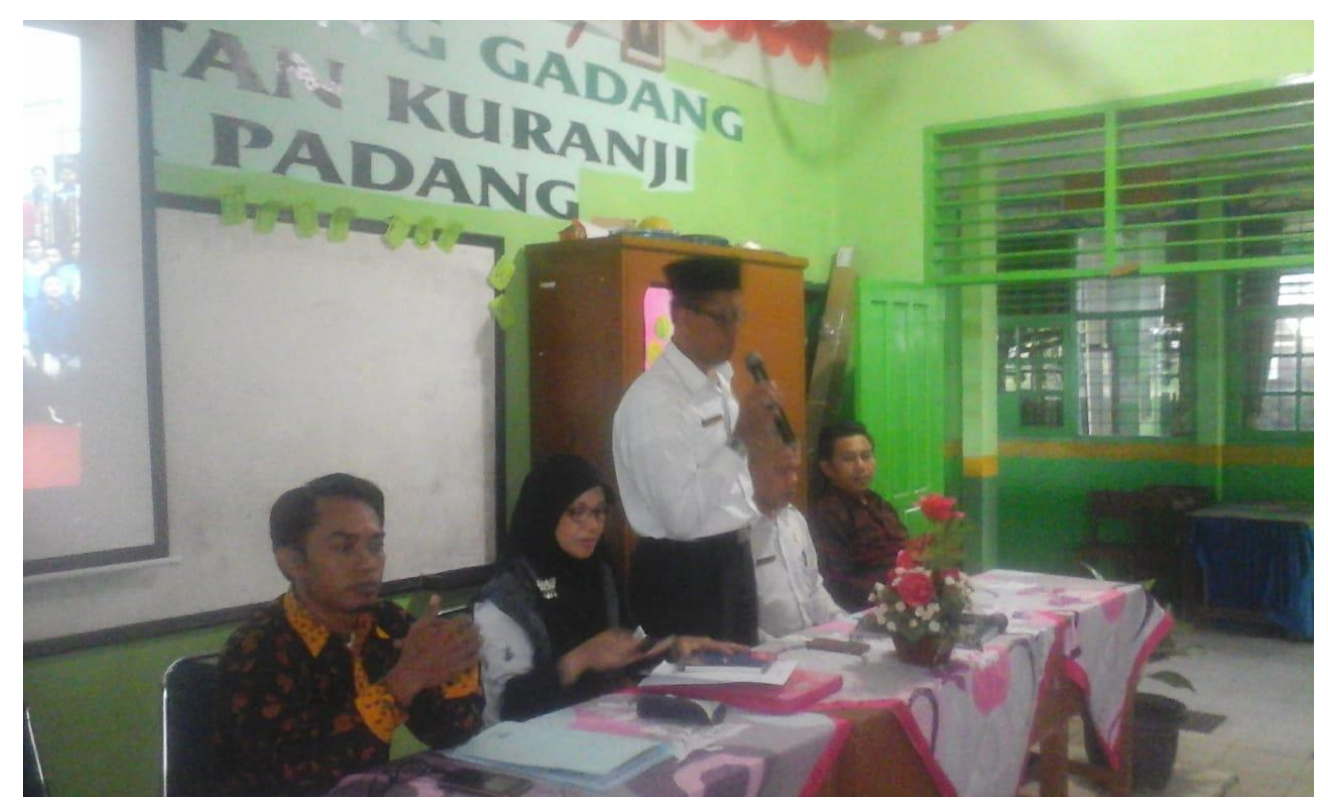

Gambar 2 . Kerjasama antara Kepala Sekolah dengan Tim (sumber : dokumen, 2021)

c. Terjalinnya mitra antara Tim Pengabdian UIN Imam Bonjol Padang dengan guru-guru Madrasah Ibtidaiyah Negeri Korong Gadang

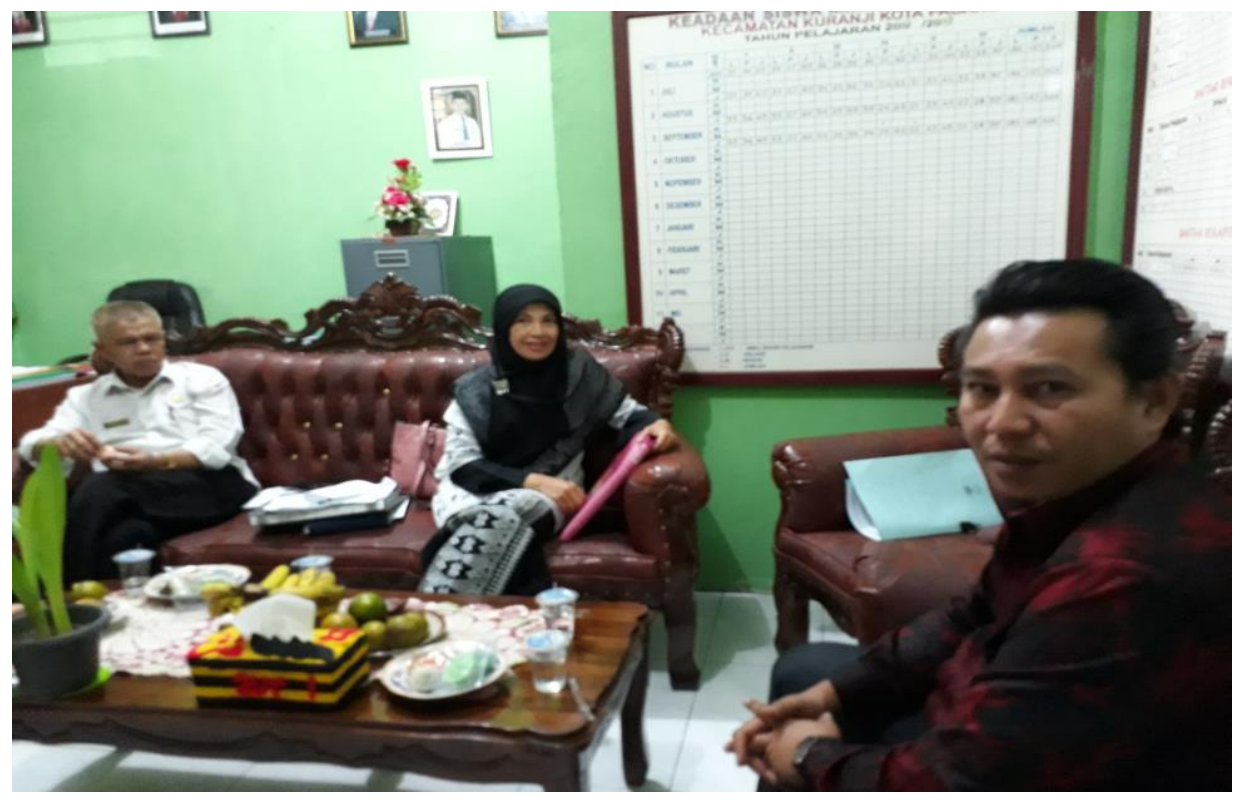

Gambar 3. Kerjasama antara Kepala Sekolah dengan Tim (sumber : dokumen, 2021)

d. Terlaksananya pelatihan membuat dokumen kurikulum dan pelaksanaannya yang bertujuan untuk meningkatkan keterampilan pedagogik dan keterampilan professional guru-guru 

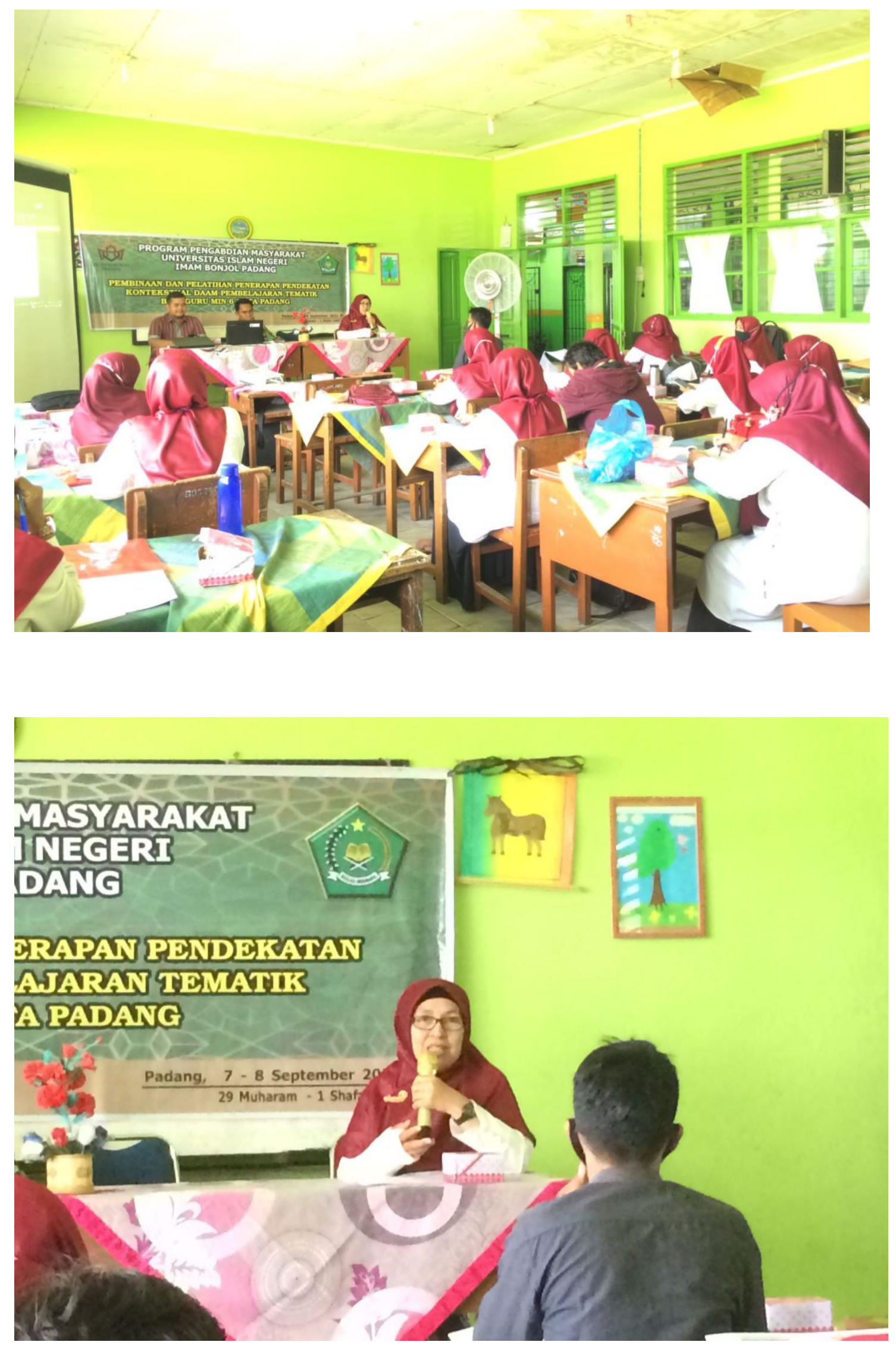


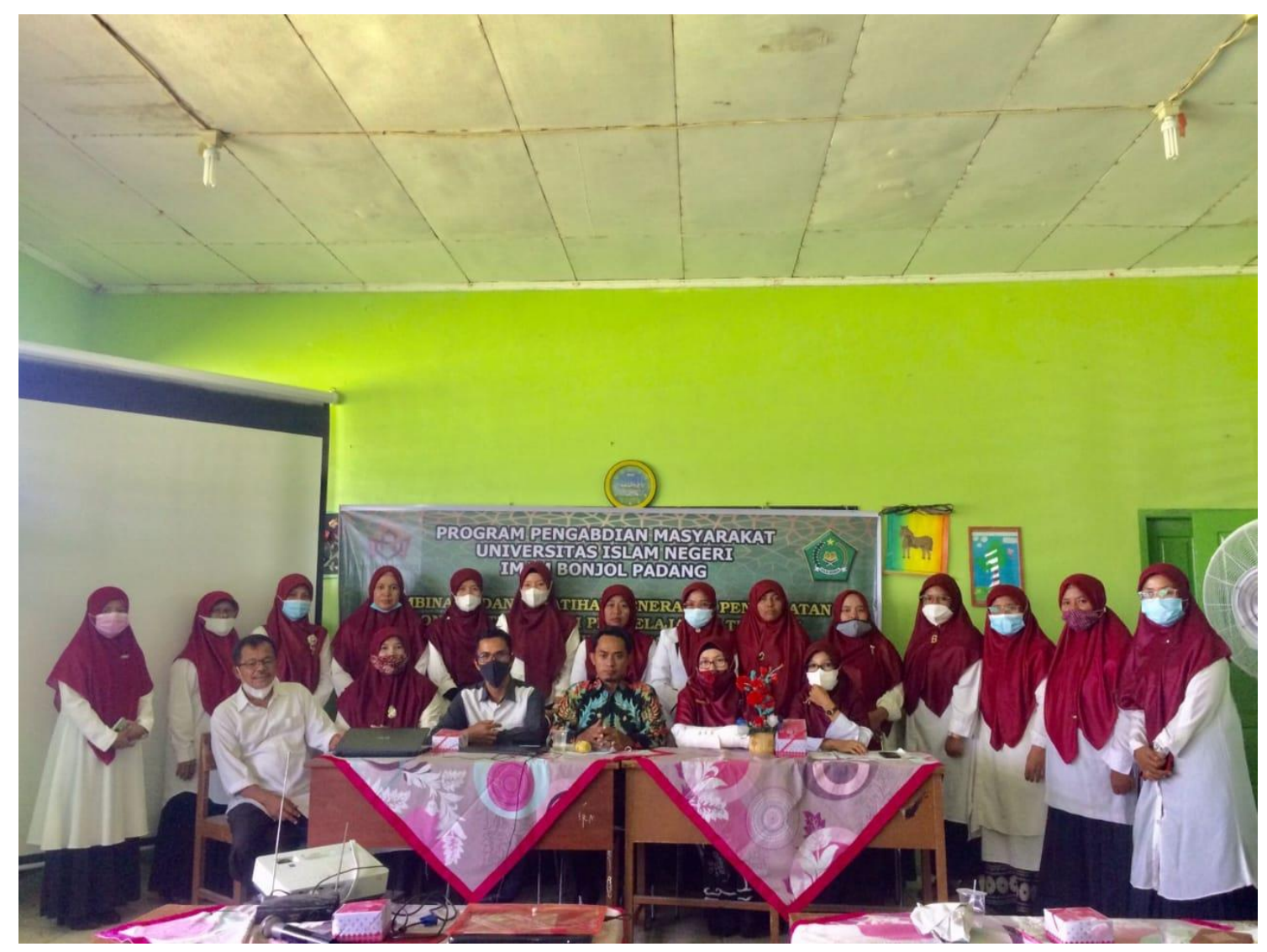

Gambar 4, 5, 6. Pelatihan penerapan pendekatan kontekstual dan pembelajaran tematik (sumber : dokumen, 2021)

\section{Discussion}

Kegiatan pengabdian ini sangat penting bagi subjek dampingan dalam hal ini Madrasah Ibtidaiyah Negeri Korong Gadang, karena guru sangat menginginkan sentuhan atau pencerahan dalam hal pendekatan kontekstual dan konsep pembelajaran tematik. Kegiatan pengabdian ini terlaksana secara baik dan sesuai dengan yang diharapkan.

Banyak dinamika keilmuan yang muncul dalam kegiatan pengabdian ini, diantaranya adalah ;

Saat pemberian materi tentang pendekatan kontekstual, hampir seluruh peserta mengajukan pertanyaan dan permasalahan untuk didiskusikan. Kegiatan tanya jawab seputar penerapan kontekstual pada pembelajaran tematik dan sistem pelaporan hasil belajar, semangat kontekstual pada kurikulum 2013, pembelajaran tematik pada kelas rendah dan tinggi dengan seru dan bersemangat. Selanjutnya juga berkembang pada materi tentang penyusunan silabus dan RPP yang bernuansa kontekstual tematik sesuai tingkat jenjang di sekolah, bagaimana penyusunan langkah prosedur pembelajaran kontekstual tematik.

Perubahan Kurikulum 2013 yang bernuansa kontekstual dengan mengusung pembelajaran tematik di MI / SD dengan revisi-revisi yang berkelanjutan ini jelas untuk memperkuat program pemerintah diantaranya Penguatan Pendidikan Karakter (PPK), Peningkatan Literacy dan Pembelajaran Abad 21. Tiga hal ini menjadi concern pemerintah untuk meningkatkan sumber daya 
manusia Indonesia. Terlebih pada pembelajaran Sekolah Dasar dan Pendidikan Pra sekolah sebagai fondasi pengetahuan dan pengembangan potensi generasi anak bangsa. Hal juga bagian dari amanat Undang-undang Sisdiknas tahun 2003.

Kegiatan pengabdian yang dilakukan dalam pendampingan penerapan pendekatan kontekstual pada pembelajaran tematik adalah:

1. Memberikan penyuluhan tentang konsep dasar pendekatan kontekstual, pembelajaran tematik, dan penyusunan dokumen kurikulum tematik berbasis kontekstual di MIN. Guru diberikan penjelasan bagaimana memahami, mempraktikkan, menyusun, merencanakan, melaksanakan dan mengevaluasi pembelajaran tematik yang kontekstual.

2. Memberikan penyuluhan tentang bagaimana konsep pendekatan kontekstual, konsep pembelajaran tematik terpadu (integratif), langkah pembuatan dokumen kurikulum tematik berbasis kontekstual yang terdiri dari (Prota, Promes, silabus dan RPP) secara menarik dari narasumber bapak Abdul Basit, M.Pd. dan bapak Debi Febianto, M.Pd.. Guru diberikan pemahaman awal tentang pendekatan kontekstual dan pembelajaran tematik agar pembelajaran di kelas lebih bermakna bagi siswa.

3. Memberikan pendampingan praktik tentang penerapan pendekatan kontekstual pembelajaran tematik pada penyusunan isi dokumen perangkat pembelajaran, dan pelaksanaannya di kelas.

4. Melakukan pendampingan secara berkala kepada guru MIN Korong Gadang, agar dapat secara mandiri menerapkan pendekatan kontekstual tematik integratif supaya pembelajaran lebih bermakna.

Pelatihan kegiatan pengabdian ini dihadiri oleh 30 orang peserta berasal dari guru-guru dan pegawai sekolah baik pustaka maupun administrasinya. Peserta 30 orang ini sangat antusias, ini terlihat dari kehadiran dan dinamika diskusi yang berkembang.

Berdasarkan hasil kegiatan yang telah dipaparkan pada hasil, bahwa kegiatan pengabdian ini mendapat respon yang positif dari para peserta, guru-guru dan kepala sekolah, dimana para peserta sangat antusias mengikuti kegiatan, dan hasilnya juga sangat baik. Guru dengan senang hati mengikuti pelatihan dari proses awal sampai akhir.

Disisi lain masih ditemukan beberapa kendala dalam pelaksanaan, misalnya menentukan waktu. Pelatihan ini dijadwalkan pagi, maka setelah jam pertama para siswa diijinkan pulang. Kendala lain adalah masih minimnya pemahaman terkait konsep pendekatan kontekstual dan tematik terpadu. Namun demikian, kerjasama yang proaktif antar guru dan kepala sekolah untuk menyelesaikan setiap latihan praktik penerapan pendekatan kontekstual, menyusun rencana pembelajaran tematik integratif (silabus dan RPP) dikerjakan dengan penuh tanggung jawab. Hal ini mengisyaratkan bahwa para guru sangat disiplin dengan waktu, walaupun memiliki kekurangan tetapi punya semangat yang besar untuk mau memahami dan terampil mengajar dengan pendekatan kontekstual dan mampu membuat perangkat silabus dan RPP tematik sebagai dokumen pembelajaran. 
Maka ke depan perlu dilakukan kembali pelatihan atau workshop tentang penyusunan materi ajar, penilaian atau evaluasi kurikulum pembelajaran untuk memudahkan para guru menyiapkan materi ajar secara baik dan mampu melakukan evaluasi secara obyektif dan dapat dipertanggungjawabkan.

\section{Conclusion}

Pengabdian yang dilakukan oleh Tim Dosen UIN Imam Bonjol Padang dan MIN Korong Gadang berupa kegiatan pendampingan penerapan pendekatan kontekstual pada pembelajaran tematik bagi guru-guru berjalan dengan baik selama bulan September 2021 dengan indikator keberhasilan, diantaranya :

1. Tersampaikannya sosialisasi program pengabdian kepada masyarakat antara program studi Pendidikan Guru Madrasah Ibtidaiyah (PGMI) dengan Madrasah Ibtidaiyah Negeri (MIN) Korong Gadang Kota Padang;

2. Terjalinnya kerjasama antara Tim Dosen Fakultas Tarbiyah dan Keguruan UIN Imam Bonjol Padang dan Madrasah Ibtidaiyah Negeri (MIN) Korong Gadang Kota Padang;

3. Terjalinnya mitra antara Tim Dosen Fakultas Tarbiyah dan Keguruan UIN Imam Bonjol Padang dan Madrasah Ibtidaiyah Negeri (MIN) Korong Gadang Kota Padang

4. Terlaksananya kegiatan pendampingan penerapan pendekatan kontekstual pada pembelajaran tematik bagi guru di Madrasah Ibtidaiyah Negeri (MIN) Korong Gadang Kota Padang yang bertujuan untuk meningkatkan keterampilan pedagogik dan keterampilan profesional guru agar pembelajaran lebih bermakna (meaningfull learning) dan meningkatkan ketercapaian tujuan pembelajaran di sekolah tersebut.

\section{Bibliography}

Arikunto, Suharsimi. (2009). Dasar-dasar Evaluasi Pendidikan. Jakarta : Bina Aksara (2006). Prosedur Penelitian Revisi VI. Jakarta : Bina Aksara.

Asma Nur. (2006). Model Pembelajaran Kooperatif. Jakarta: Depdiknas

Dahar, Ratna, Wilis. (1990). Teori-teori Belajar. Jakarta : Erlangga.

Departemen Pendidikan Nasional. (2002). Manajemen Peningkatan Mutu Berbasis Sekolah: Buku 5 Pembelajaran dan Pengajaran kontektual. Jakarta: Depdiknas.

Departemen Pendidikan Nasional. (2007). Standar Kompetensi dan Kompetensi Dasar Tingkat SD/MI. Jakarta: Depdiknas. 
Depdiknas. (2006). Pembelajaran Tematik Kelas awal SD.Jakarta Pusat.

Hamalik, Oemar. (2002). Psikologi Belajar dan Mengajar.Bandung:Sinar Baru Algesindo

Hudojo, Herman. (1990). Strategi Belajar Mengajar Matematika. Malang : IKIP.

Johnson, Elaine B. (2007). Contextual Teaching and Learning (Menjadikan Kegiatan Belajar Mengajar Mengasyikan dan Bermakna). Bandung: Mizan Media Utama.

Moleong, Lexi J. (1995). Metode Penelitian Kualitatif. Bandung: Remaja Rosda Karya.

Marzuki. 1985. Metodologi Reserch. Jakarta.

Muslich, Masnur. (2007). KTSP Pembelajaran Berbasis Kompetensi dan Kontekstual. Jakarta: Bumi Aksara.

Nurhadi, dkk. (2004). Pembelajaran Kontekstual dan Penerapannya dalam KBK. Malang: Universitas Negeri Malang.

Nasution, S. (2002). Metode Reserch (Penelitian Ilmiah). Jakarta: Bumi Aksara.

Sanjaya, Wina. (2007). Strategi Pembelajaran (Berorientasi Standar Proses Pendidikan). Jakarta: Kencana Prenada Media

Sukardi. (2003). Metodologi Penelitian Pendidikan. Yogyakarta: Bumi Aksara.

Suryanti, dkk. (2009). Model-model Pembelajaran Inovatif. Surabaya: Unesa University Press.

Trianto, (2007). Model-model Pembelajaran Inovatif Berorientasi Konstruktivistik. Surabaya: Prestasi Pustaka Publisher. 